\title{
DISCLAIMER
}

This report was prepared as an account of work sponsored by an agency of the United States Government. Neither the United States Government nor any agency thereof, nor any of their employees, makes any warranty, express or implied, or assumes any legal liability or responsibility for the accuracy, completeness, or usefulness of any information, apparatus, product, or process disclosed, or represents that its use would not infringe privately owned rights. Reference herein to any specific commercial product, process, or service by trade name, trademark, manufacturer, or otherwise does not necessarily constitute or imply its endorsement, recommendation, or favoring by the United States Government or any agency thereof. The views and opinions of authors expressed herein do not necessarily state or reflect those of the United States Government or any agency thereof.

WSRC-MS- $-91-049$

DE92 009648

\section{TRITIUM CONFINEMENT IN A NEW TRITIUM PROCESSING FACILITY AT THE SAVANNAH RIVER SITE (U)}

by

L. K. Heung, et al

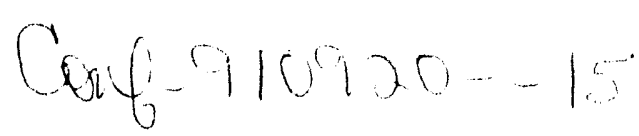

Westinghouse Savannah River Company

Savannah River Site

Aiken, South Carolina 29808

An abstract of a paper proposed for presentation and publication at the

Fourth Topical Meeting on Tritium Technology

in Fission, Fusion, and Isotopic Applications

Albuquerque, New Mexico

September 29 - October 4, 1991

This paper was prepared in connection with work done under Contract No. DE-AC09-89SR18035 with the U.S. Department of Energy. By acceptance of this paper, the publisher and/or recipient acknowledges the U.S. Government's right to retain a nonexclusive, royalty-free license in and to any copyright covering this paper, along with the right to reproduce and to authorize others to reproduce all or part of the copyrighted paper.

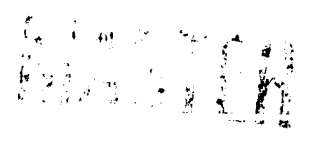




\title{
TRITIUM CONFINEMENT IN A NEW TRITIUM PROCESSING FACILITY AT THE SAVANNAH RIVER SITE
}

\author{
by \\ L. K. Heung, J. H. Owen, R. H. Hsu, R. F. Hashinger, D. E. Ward and P. E. Bandola \\ Westinghouse Savannah River Company, Savannah River Site, Aiken, SC 29808, USA
}

\begin{abstract}
A new tritium processing facility, named the Replacement Tritium Facility (RTF), has been completed and is being prepared for startup at the Savannah River Site (SRS). The RTF has the capability to recover, purify and separate hydrogen isotopes from recycled gas containers. A multilayered confinement system is designed to reduce tritium losses to the environment. This confinement system is expected to confine and recover any tritium that might escape the process equipment, and to maintain the tritium concentration in the nitrogen glovebox atmosphere to less than $10^{-2} \mu \mathrm{Ci} / \mathrm{cc}$ tritium.
\end{abstract}

\section{INTRODUCTION}

Tritium processing operations at the Savannah River Site (SRS) began in 1955. ${ }^{1}$ Tritium is produced by irradiating lithium in nuclear reactors, extracted and purified in tritium processing facilities. Most of the tritium produced at SRS is loaded into sealed containers for the national defense programs. The sealed containers are recycled periodically, and the tritium is recovered for reuse. Existing tritium processing facilities at SRS are over 30 years old. A new facility, called the Replacement Tritium Facility (RTF), to replace the old container loading, sealing and unloading facility has been built and is being prepared for startup. Process design of this new facility has been described elsewhere. 1,2 Reduced tritium loss to the environment is one of the key objectives of the new facility. In this paper the RTF tritium confinement system will be presented

\section{OVERVIEW OF THE RTF CONFINEMENT SYSTEM}

To reduce tritium loss to the environment, the new facility uses a multilayered confinement system:

(1) Gloveboxes provide Secondary containment: All tritium processing equipment is installed in sealed gloveboxes; tritium transfer lines outside the gloveboxes are contained in stainless steel jackets; both the gloveboxes and the transfer line jackets are filled with a nitrogen atmosphere.

(2) Primary and secondary strippers clean up the glovebox atmosphere: The nitrogen is continuously circulated through a primary stripper system during normal operation to remove any tritium which might have escaped the process equipment; in the event of an accidental tritium release the nitrogen in that specific glovebox will be circulated through a secondary stripper system to speed up the clean-up. 
(3) Purge stripper further cleans up the purge gas: Nitrogen purge from the gloveboxes is further stripped of tritium in a purge stripper before it is released to the environment.

(4) Zeolite bed recovery system recovers the tritium: All the tritiated water accumulated in the stripper system is recovered through a zeolite bed regeneration system.

A schematic of the glovebox-stripper system is shown in Fig. 1.

\section{THE GLOVEBOXES}

A total of 30 gloveboxes are used to contain all the process equipment. The total glovebox volume is about $680 \mathrm{~m}^{3}$ with individual boxes varying from 12 to $45 \mathrm{~m}^{3}$. The gloveboxes and the transfer line jackets are filled with nitrogen at a negative pressure of $-1.27 \mathrm{~cm}$ water relative to the surrounding room pressure, so that any gas leakage will be into the gloveboxes and jackets. The negative pressure is maintained by automatic purging and addition of nitrogen. Each glovebox is also equipped with two bubblers, designed to limit the maximum pressure difference between the glovebox and the surrounding room atmosphere to $5 \mathrm{~cm}$ water. A schematic of the design of the bubblers is shown in Fig.2. The gloveboxes are divided into two groups of 15 gloveboxes each. Each group is normally served by one of two primary stripper systems. In case $o_{i}^{f}$ an accidental tritium release from the process, individual gloveboxes can be connected to a secondary stripper system. Thereby high tritium activity in one particular glovebox will be isolated from the primary stripper and connected to the secondary stripper until the tritium concentration is back to the normal level.

Main impurities in the glovebox nitrogen are expected to be oxygen, water vapor and tritium. Their levels will be maintained at less than $1 \%$ oxygen by volume, $300 \mathrm{ppm}$ water by volume and $10^{-1} \mu \mathrm{Ci} / \mathrm{cc}$ tritium, through the use of the stripper system and controlled purging.

The temperature in each glovebox is kept between 17 to $25^{\circ} \mathrm{C}$ by circulating the nitrogen through a heat exchanger cooled by chilled water. The circulation rate is based on the heat load of each individual glovebox. Each glovebox is equipped with an ion chamber to monitor the tritium level, and oxygen, moisture and combustible gas meters.

\section{THE PRIMARY AND SECONDARY STRIPPER SYSTEMS}

The function of the primary and secondary stripper system is to remove tritium from the glovebox nitrogen and to return the clean nitrogen back to the gloveboxes. The primary and secondary stripper systems are identical in design. Each consists of a preheater, a catalyst bed, a precooler, three zeolite beds, and two blowers. See Fig. 3. The gas flow rate for each system is 2.8 $\mathrm{m}^{3} / \mathrm{min}$ with only one of the two blowers on-line at a given time. The other blower is on standby. Each primary system serves 15 gloveboxes. The secondary system is on standby and can be connected to any glovebox in case 
of an accidental tritium release. It should connected to no more than 3 gloveboxes at the same time.

The preheater is electrically heated and can increase the incoming gas temperature to $400{ }^{\circ} \mathrm{C}$ as needed. The catalyst bed is divided into two chambers. The top chamber holds a palladium on alumina catalyst (Deoxo $D \circledast$ by Engelhard). The bottom chamber holds a coppei on alumina oxygen getter (Q-5 ${ }^{\circledR}$ by Dow) The catalyst bed is normally operated at room temperature, which is sufficient for the Deoxo $D$ to catalyze the oxidation of elemental tritium effectively under low moisture conditions. When tritiated organics like methane are suspected in the nitrogen, the catalyst bed temperature can be raised to 400 ${ }^{\circ} \mathrm{C}$. The higher temperature is needed in order to oxidize the organics. The dual temperature operation conserves energy and extend the service life of the heaters. The oxygen getter was designed to remove excessive oxygen, so that the oxygen level in the glovebox is maintained at about $1000 \mathrm{ppm}$. Experience gained during preparation for startup has shown that maintaining the oxygen at such a low level in the glovebox is both unrealistic and unnecessary. The target oxygen level has been raised to $10,000 \mathrm{ppm}$, and the oxygen getter has become unnecessary. The hot gas leaving the catalyst bed is cooled to below $30{ }^{\circ} \mathrm{C}$ by chilled water in a precooler, before it enters the zeolite bed for water removal.

The three zeolite beds are connected in parallel. Only one of them is on-line at any given time. The other two are either on standby or being regenerated. Type $3 \mathrm{~A}$ zeolite is used in the beds. Zeolite $3 \mathrm{~A}$ does not adsorb $\mathrm{CO}_{2}$ as the other types do, so that the $\mathrm{CO}_{2}$ generated by the oxidation of organics does not accumulate in the zeolite beds. The moisture content in the gas leaving the zeolite bed is expected to be less than $1 \mathrm{ppm}$, and the tritium content is expected to be less than $10^{-2} \mu \mathrm{Ci} / \mathrm{cc}$. About $1 \%$ of the $2.8 \mathrm{~m}^{3} / \mathrm{min}$ nitrogen will be purged through the purge stripper to the stack. The rest is returned to the gloveboxes.

\section{THE PURGE STRIPPER SYSTEM}

The function of the purge stripper system is to further reduce the tritium content in the purge nitrogen before it is sent to the stack. Purging of the glovebox nitrogen at an average rate of about $0.03 \mathrm{~m}^{3} / \mathrm{min}$ is necessary in order to maintain the target oxygen level and to control the glovebox pressure. The purge stripper system consists of three beds filled with palladium deposited on zeolite (Pd/zeolite), and two sets of pumps. Each set consists of a blower and a metal bellows purnp in series. Only one set of the of the pumps is in operation at any given time. The other is on standby. The maximum gas flow rate is 0.15 $\mathrm{m}^{3} / \mathrm{min}$.

The three $\mathrm{Pd} /$ zeolite beds are connected in parallel. Only one of them is on-line at any given time. The other two are either on standby or being regenerated. These Pd/zeolite beds are operated at room temperature. The Pd catalyzes the 
oxidation of tritium and the zeolite adsorbs the water. In this way the functions of a catalyst and a zeolite bed are combined into one single bed. A factor of 10 reduction in tritium concentration is expected.

\section{THE ZEOLITE BED RECOVERY SYSTEM}

The function of the recovery system is to remove the water from the zeolite beds including the $\mathrm{Pd} /$ zeolite beds, and to reduce the water to molecular hydrogen for later recovery of the tritium. The tritium is recovered through an isotopes purification and separation system. All the zeolite beds are piped to two identical recovery systems, and may be recovered by either one.

Each recovery system consists of a biower and a metal bellows pump connected in series, a uranium bed and a recovery tank. See Fig. 5. During recovery operation, a zeolite bed is isolated from the stripper system and is valved to the recovery system. The uranium bed is heated to $400^{\circ} \mathrm{C}$. A small amount of protium is used to fill the system piping to a pressure of 200 torr. The pumps are started to circulate the gas through the zeolite bed and the uranium bed. At the same time the zeolite bed is heated to desorb the water into the gas stream. When the water vapor passes through the uranium bed, it reacts with the uranium to form uranium oxide and molecular hydrogen.

As more and more water is desorbed and reduced, the pressure in the recirculation loop increases. When the pressure reaches 1520 torr, a valve leading to the recovery tank located down stream of the uranium bed is opened to remove some of the gas until the pressure is back to about 760 torr. When the pressure in the system stops increasing the zeolite bed is considered regenerated. The gas collected in the recovery tank is expected to be mostly protium with less than about $0.05 \%$ tritium. The gas is then sent to an isotope purification system to recover the tritium.

\section{MATERIAL BALANCE}

Tritium, protium, nitrogen, oxygen and water vapor are the key gas components in the glovebox-stripper system. Tritium comes from leakage of the process equipment and ends up in the recovery tanks. Protium comes mainly from the moisture in the air which leaks into the gloveboxes and permeates through the gloves, also ending up in the recovery tanks. Nitrogen is added to the system as required to make up for purging and for atmospheric pressure changes. Oxygen comes from air in-leakage and moisture permeating through the gloves. $A$ small part of this oxygen is used to oxidize the tritium and ends up in the uranium bed of the recovery system. The rest of the oxygen is purged to the stack through the purge stripper. The oxygen level in the gloveboxes is monitored and controlled at less than 1 vol\% by adjusting the purge rate. The amount of tritium purged with the purge stream is expected to be less than 100 $\mathrm{Ci} /$ year. More than $99.9 \%$ of the moisture in the system is from the glovebox inleakage and permeation through the gloves. All of this water is adsorbed in the 
zeolite bed together with a very small amount of tritiated water. The amount of uranium required to reduce the water is about $70 \mathrm{~kg} / \mathrm{year}$.

\section{DISCUSSIONS}

Stripper systems at other Department Of Energy sites were visited and studied when the glovebox-stripper system for RTF was designed. 3,4,5,6 Many of the design parameters that were selected were based on the experience of these other stripper systems and on our own operating experience with the existing stripper system at the Savannah River Site. Although all these systems are based on the same oxidation and adsorption principle, no two of them are exactly the same. The RTF is presently being prepared for start-up. There have been no major problems with the glovebox-stripper system. The RTF gloveboxes are expected to be maintained at less than $10^{-1} \mu \mathrm{Ci} / \mathrm{cc}$, and the purge stream to be less than $10^{-2} \mu \mathrm{Ci} / \mathrm{cc}$. Operation and performance data should be available sometime in 1992.

\section{REFERENCES}

1. M. S. Ortman, L. K. Heung, A. Nobile, and R. L. Rabun III, "Tritium processing at the Savannah River Site: Present and future", J. Vac. Sci. Technol. A 8 (3), p2881, May/Jun, 1990.

2. T. Motyka, "The Replacement Tritium Facility", to be presented at the Fourth Topical Meeting on Tritium Technology in Fission, Fusion, and Isotopic Applications, Sept. 1991.

3. P. H. Lamberger and G. E. Gibbs, "Tritium Effluent Removal System", Presented at 15th DOE Nuclear Air Cleaning Conference.

4. J. L. Anderson, F. A. Damiano and J. E. Nasise, "Tritium Handling Facilities at the Los Alamos Scientific Laboratory", Proceedings of the 23rd Conference on Remote Systems Technology, 1975.

5. J. E. Nasise, Los Alamos National Laboratory Report LA-UR 80-1265, "Performance and Improvements of the Tritium Handling Facility at the Los Alamos Scientific Laboratory", 1980.

6. P. Gildea, Sandia National Laboratory Report SAND 85-8606, "Operating Experience with the Sandia Tritium Facility Cleanup Systems", 1985. 


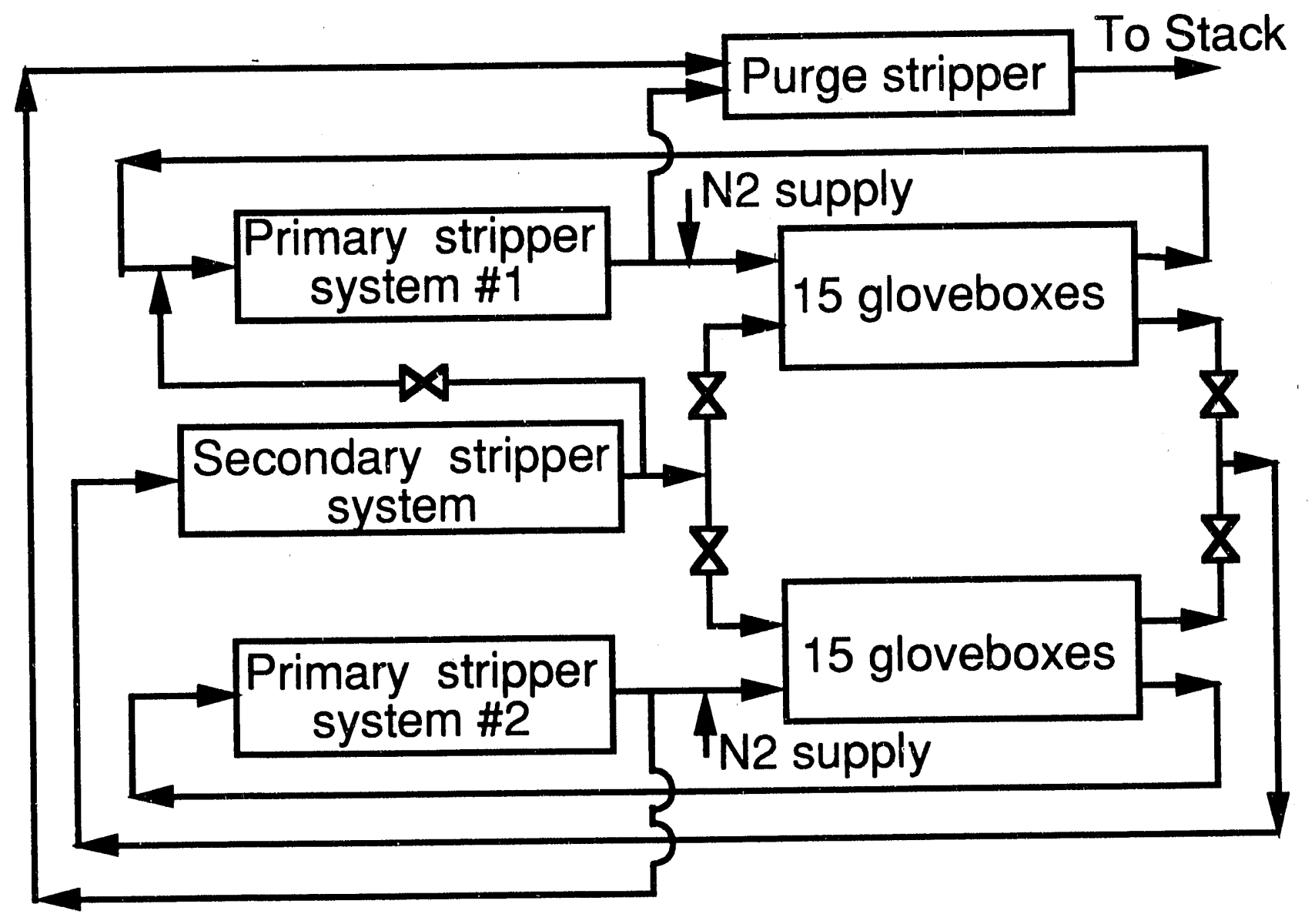

Fig. 1. Glovebox-stripper system flow diagram 


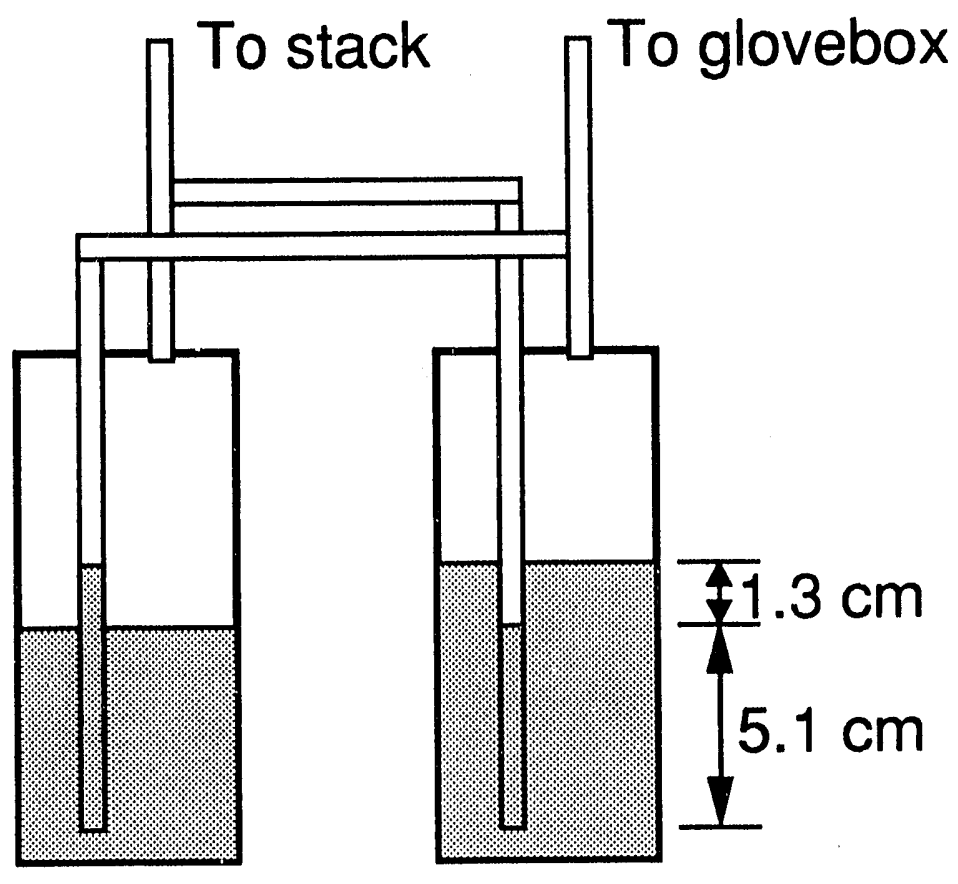

Fig.2. Glovebox bubblers 


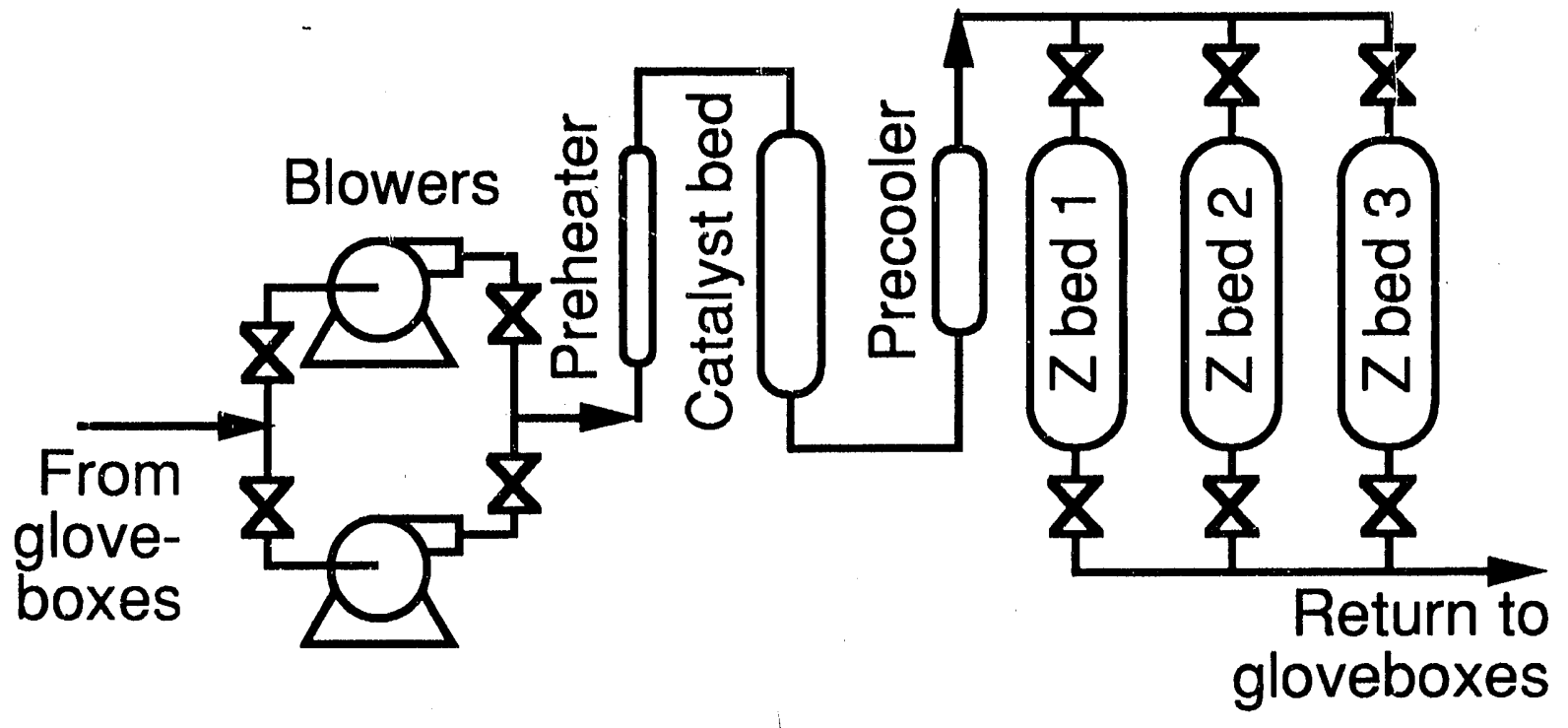

Fig. 3. Flow diagram of primary and secondary strippers. 


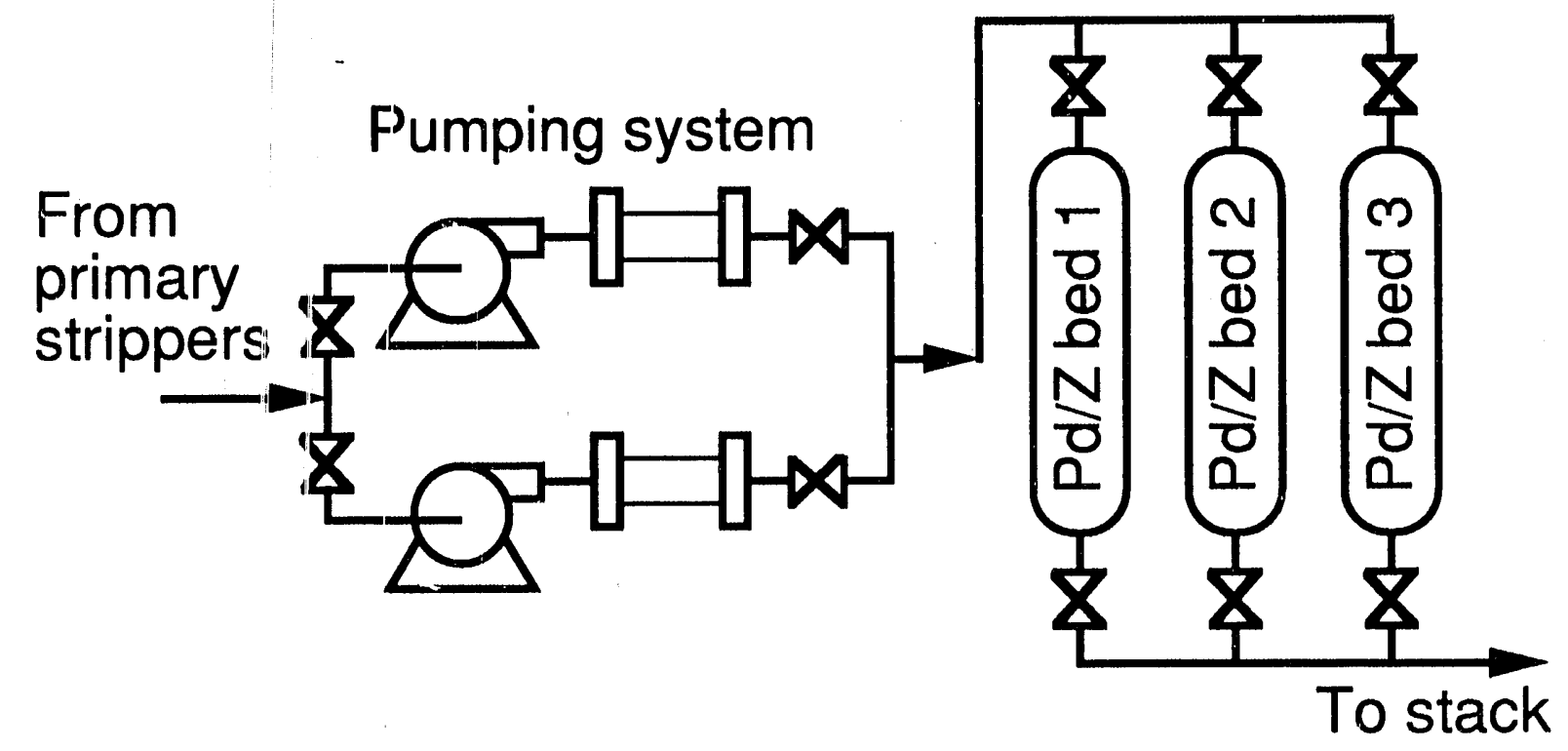

Fig. 4. Purge stripper flow diagram 


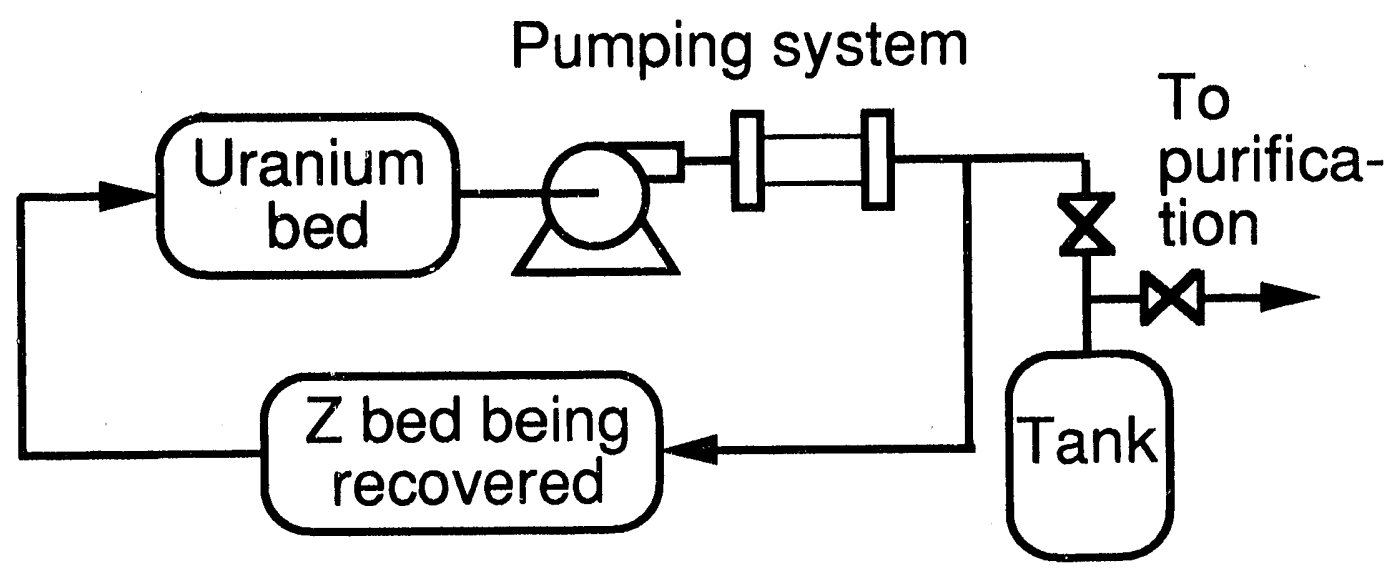

Fig. 5. Zeolite bed recovery system 


\section{TOTAL QUALITY SURVEY}

(Optional)

Customer

WSRC CLASSIFICATION OFFICE

Information

Name

Department/Section

Building

This Office recently-assisted you in making a classification determination. We value you as a customer and wish your comments on how our service was. We wish to maintain a high quality of service. In order to ensure this goal is met and maintained please answer the following questions.

1. Name of Classification Analyst who provided assistance.

Please rate the following quality areas on a scale of 1 to 5 by circling; 5-excellent; 4-above average; 3-average; 2-below average; 1-poor.

2. Rate the timeliness of the classification review or guidance provided by the Classification Analyst. When answering this question consider the following questions. Did the Classification Analyst complete your work as promised. Was the work delayed due to actions beyond the Analyst's control?
1
2
3
4
5

\section{Comments}

3. Rate the communications between you and the Classification Analyst. When answering this question consider the following questions. Was the Classification Analyst knowledgeable of your work and the classification issues associated with . Was the Classification Analyst interested in your needs?
1
2
3
4
5

\section{Comments}

4. Rate the quality of the classification guidance that was given. When answering this question consider the following question. Was the classification guidance provided by the Classification Analyst clear and specific to your needs?
1
2
3
4
5

\section{Comments}

5. Would you like follow-up communications? _ Yes _ No Fold, staple or tape, and return by site mail. 

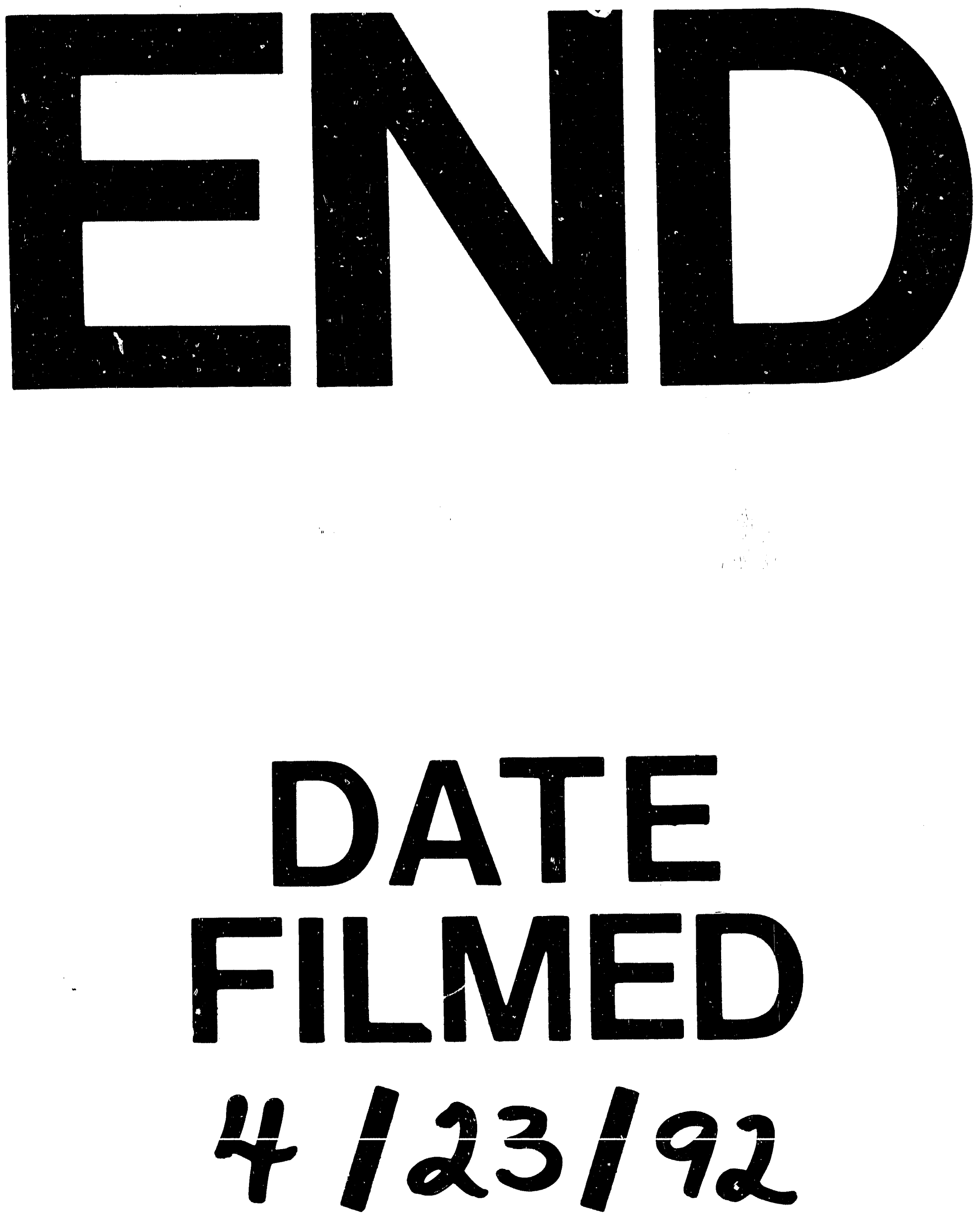
